\title{
Experimental investigation on the friction characteristics of hazelnut powder reinforced brake pad
}

\author{
Gülşah Akıncıoğlu ${ }^{1}$, Sitkı Akıncıoğlu ${ }^{2}$, Hasan Öktem ${ }^{3}$ and İlyas Uygur ${ }^{4}$ \\ ${ }^{1}$ Department of Machine Design and Construction, University of Düzce, Turkey, e-mail: gulsahakincioglu@ gmail.com \\ ${ }^{2}$ Department of Machine Design and Construction, University of Düzce, Turkey, e-mail: sitkiakincioglu@gmail.com \\ ${ }^{3}$ Department of Machine, Kocaeli University, Turkey, e-mail: hoktem@kocaeli.edu.tr \\ ${ }^{4}$ Department of Machine Engineering, Duzce University, Turkey, e-mail: ilyasuygur@ duzce.edu.tr
}

\begin{tabular}{|c|c|}
\hline Article Info & ABSTRACT \\
\hline & \multirow{7}{*}{$\begin{array}{l}\text { After the realization that asbestos fiber is harmful to human health, efforts to } \\
\text { produce organic and environmentally friendly brake pads have increased. In } \\
\text { this study, an environmentally friendly brake pad (NUS sample) was produced } \\
\text { with the addition of } 3.5 \% \text { hazelnut shell powder. Hardness and density } \\
\text { measurements of the brake pad sample were made. Chase type device was used } \\
\text { for the wear and friction tests. The experiments were done according to the } \\
\text { SAE J661 standard. The average friction coefficient value obtained as a result } \\
\text { of the experiments was found to be } 0.435 \mu \text {. Bu değer standartlara uygundur } \\
\text { ve "FF" sinifi aralığindadır. This value complies with the standards and is in } \\
\text { the "FF" class range. } \\
\text { Copyright } @ 2020 \text { Regional Association for Security and crisis management } \\
\text { and European centre for operational research. } \\
\text { All rights reserved. }\end{array}$} \\
\hline Received January 12, 2021 & \\
\hline Revised February 10, 2021 & \\
\hline Accepted February 20, 2021 & \\
\hline \multirow{3}{*}{$\begin{array}{l}\text { Keywords: } \\
\text { Brake Pad, } \\
\text { Walnut Shell Dust, } \\
\text { Organic Additive, } \\
\text { Wear-Friction. }\end{array}$} & \\
\hline & \\
\hline & \\
\hline \multicolumn{2}{|l|}{ Corresponding Author: } \\
\hline \multicolumn{2}{|c|}{$\begin{array}{l}\text { Gulşah Akıncığlu, } \\
\text { Department of Machine Design and Construction, University of Düzce, Turkey. } \\
\text { Email: gulsahakincioglu@ @mail.com }\end{array}$} \\
\hline
\end{tabular}

\section{Introduction}

Brake pad is a composite used in many motor vehicles and contains dozens of different powder materials. It has been revealed that asbestos dust, which was widely used in its content in the past years, is harmful to human health (Selikoff and Lee, 1978; Pinca-Bretotean et al., 2018). With the realization that asbestos is harmful, the search for new materials that are environmentally friendly and do not harm human health has started (Chan and Stachowiak, 2004). A stable friction coefficient is expected from brake pads under dry and wet braking conditions (Leman et al., 2008). It is desired to produce composites that do not harm the environment and human health and also show a good braking performance. This situation has led researchers to natural additives. Studies have been made especially for the use of regional products. It is aimed to evaluate regional products economically. Singaravelu et al. (2019) produced a brake pad sample with the addition of crab shell powder (CBS), which is abundant in their area of residence. They used $12 \%$ of the crab shell powder in the composite. They performed their abrasion friction tests on the Chase type wear friction device. They made the comparison with a sample without crab shell powder. They obtained the Feyd rate of the CBS sample as $1.71 \%$. As a result, they observed that the tribological properties of the CBS sample were better and the friction coefficient was more stable than the other sample. In another study, Bretotean et al. (2018) produced a brake lining sample by adding $10 \%$ coconut fiber. They tested the sample on a specially designed test device. They found the average friction coefficient 0.35 . They observed that, according to the average friction coefficient value, the sample they produced could be used in small and medium-sized vehicles. Rajaramana et al. (2020) tried bamboo fiber as a natural additive in their studies. They concluded that bamboo fiber positively 
affects the mechanical and physical properties of brake pads and can be used in commercial brake pads. Öktem and Uygur (2019) produced a brake pad with hazelnut shell and examined its performance in a specially designed wear device. They carried out the experiments in the wear device at $30-90{ }^{\circ} \mathrm{C}$ and $95-180{ }^{\circ} \mathrm{C}$ and carried out the experiments in the wear device at $30-90{ }^{\circ} \mathrm{C}$ and $95-180^{\circ} \mathrm{C}$. They determined the braking number as 100, 500 and 1000 and achieved the most stable wear and friction behavior at 1000 braking cycles. Jeganmohan et al. (2020) powdered palm kernel and used it as a natural additive. They added 3\%, 6\% and 9\% palm kernel powder to the brake pad sample, respectively. They did not add palm kernel powder to one of the samples, and the best performance was achieved with this sample and the sample with $3 \%$ palm kernel powder. They conclude that palm kernel powder should not exceed 3\%. Sugözü (2018) produced brake pad with $8 \%$ and $12 \%$ pinus nigra cone powder. He used another sample without pinus nigra cone powder for comparison. Friction wear tests were carried out at a temperature of $200-250^{\circ} \mathrm{C}$. The highest friction coefficient value was obtained from the sample with $8 \%$ pinus nigra cone powder as $0.30 \mu$. It has been observed that as an additive, pinus nigra cone powder has a positive effect on the braking performance. Devoor et al. (2018) in their research, obtained samples with natural additives by pulverizing the shells of coconut and simaruba plant. They produced samples with a diameter of $10 \mathrm{~mm}$ in accordance with the test device. The samples were pressed at $15 \mathrm{MPa}$ pressure at $150{ }^{\circ} \mathrm{C}$ for 10 minutes. They used $0 \%, 10 \%, 20 \%, 40 \%$ and $50 \%$ coconut + simaruba additives, respectively. They observed the highest coefficient of friction in the sample, which contains the most coconut and simaruba shell. This value is $0.456 \mu$. The friction coefficient value of the sample, which does not contain coconut + simaruba, is $0.259 \mu$. They concluded that the added natural additives increase the friction coefficient.

When the literature is reviewed, it is observed that various - especially agricultural - additives are found in the brake pad composite. In our study, the hazelnut plant, which is widely cultivated in our country, was used. It is aimed to evaluate the hazelnut shell produced as waste. A new brake pad sample (NUS) was produced with the addition of $3.5 \%$ hazelnut shell powder. The hardness and density of the brake pad sample was measured. Wear and friction tests were applied on the Chase type device.

\section{Material and Method}

\subsection{Brake Pad Production Process}

A real-size brake pad was produced with the hazelnut shell powder, a natural additive material. First, the powders to be used in the content of the composite were determined. Steel wool, rock wool and kevlar reinforcement material; phenolic resin, rubber powder and sulfur binder; vermiculite, calcium hydroxide and barite filling material; graphite and brass chips friction adjuster; zirconium silicate and black iron oxide were used as abrasives. The content of the composite was completed by adding $3.5 \%$ hazelnut shell powder to these materials. After the determined powders are weighed with a precision scale, they are mixed with an industrial type mixer. Before the brake pads are pressed, the pressure on the brake pad surface was calculated. The pressure calculation applied in the pressing process is made according to Equation (1).

$P_{m}=\frac{S_{B} \cdot n \cdot P_{B}}{s_{p}}=\frac{36.10 .150}{491} \cong 110.000 \mathrm{~kg}=110$ ton

$110 \times 1,1=121$ Ton obtained. (The value of 1.1 is the pressure coefficient.)

According to Equation $\mathrm{P}_{\mathrm{m}}=$ Manometer pressure, $\mathrm{S}_{\mathrm{B}}=$ Break Pad surface area $\left(\mathrm{cm}^{2}\right), \mathrm{n}=$ The number of cells in the brake pad mold, $\mathrm{S}_{\mathrm{p}}=$ Press piston area, $\mathrm{F}_{\mathrm{B}}=$ Total force on the brake pad surface, $\mathrm{P}_{\mathrm{B}}=$ The total pressure on the brake pad surface.

According to $F_{B}=S_{B} \times P_{B}=36 \times 150=5400 \mathrm{~kg}$; The pressure on the pad surface is calculated according to Equation (2).

$P_{B}=\frac{F_{B}}{S_{p}}=\frac{5400}{491}=11 \mathrm{~kg} / \mathrm{cm}^{2}$

The mixture is pressed into a mold of a commercial brake pads. The brake pads are produced by pressing at $100 \mathrm{~kg} / \mathrm{cm}^{2}$ pressure at $180^{\circ} \mathrm{C}$ for 6 minutes. During pressing, the press is withdrawn from the mold 3 times for 10 seconds and air outlet is provided. After the pressing process, the brake linings are grinded for dimensional accuracy. Prepared brake pads were baked at $150^{\circ} \mathrm{C}$ in the oven for 10 hours. Baked brake pads are ready for tests. 


\subsection{Brake Pad Hardness Measurement}

The hardness of the brake pad samples were measured with Shore D hardness tester. For hardness values, measurements were made from 5 different points of the surface of the brake pad. These measurements were averaged.

\subsection{Brake Pad Density Measurement}

Density test was made according to ASTM D792 standard with Archimedes principle. Density tests were performed using Radwag brand precision scale and density kit.

\subsection{Wear-Friction Tests of Brake Pads}

Wear- friction tests of the produced brake lining samples were performed in Pyramid Precision Engineering brand Chase type wear friction device according to SAE J661 standard. In the Chase type test system, the brake pad sample rubs against a rotating drum. Drum material is gray cast (DDL-20) iron. Maximum rotation speed of drum is $411 \mathrm{rpm}$ and maximum applied load is $68 \mathrm{~kg}$. Brake pad samples were prepared in $25 \mathrm{~mm}$ x $25 \mathrm{~mm}$ x $40 \mathrm{~mm}$ dimensions for testing. The test sample prepared for the Chase type test device is given in Figure 1.

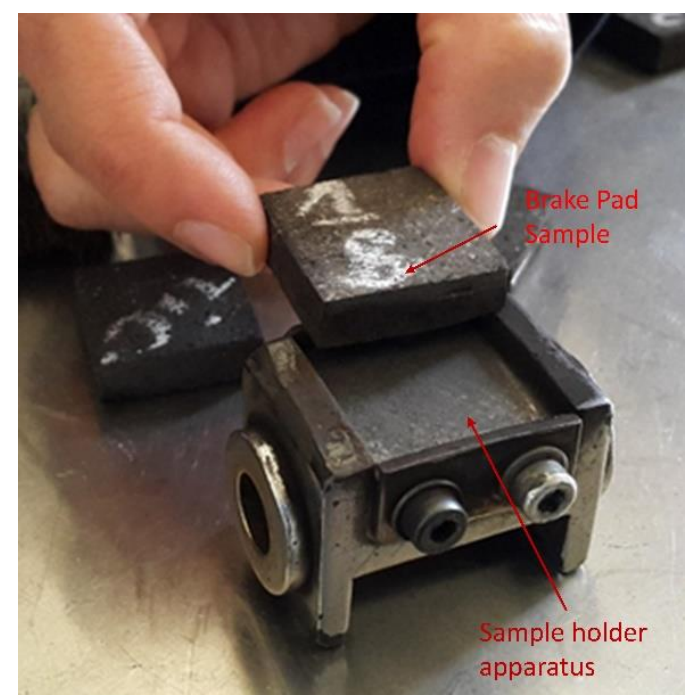

Figure 1. Brake pad sample and chase type sample holder apparatus

The Chase type device used in the experiments is shown in Figure 2. The friction coefficient is divided into cold (normal) and hot friction coefficient. Cold friction coefficient measurements were made at $100^{\circ} \mathrm{C}, 150^{\circ} \mathrm{C}$ and $200^{\circ} \mathrm{C}$. In the hot friction coefficient, measurements were made at $300{ }^{\circ} \mathrm{C}, 350{ }^{\circ} \mathrm{C}$ and $400{ }^{\circ} \mathrm{C}$.

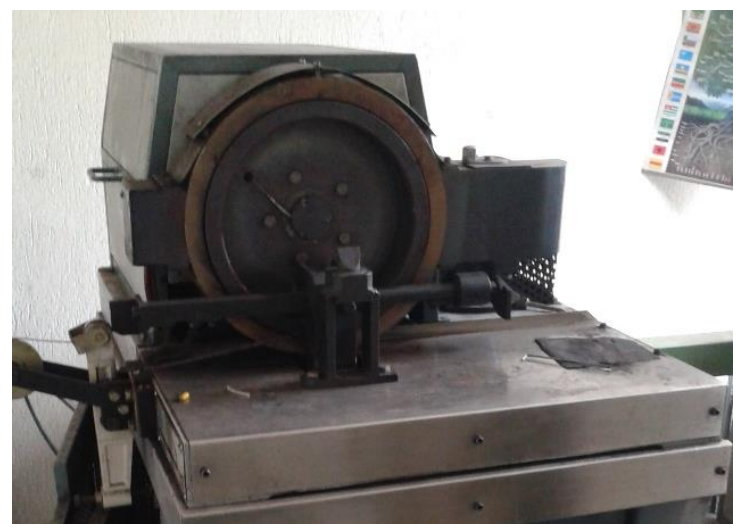

Figure 2. Chase type test device, 


\section{Results and Discussion}

\subsection{Brake Pad Hardness Measurement}

As a result of the measurements made with the Shore D hardness tester, the hardness value of the hazelnut shell powder added brake pad sample was obtained as "88 Shore D". Akıncığlu et al. produced 3.5\% and 7\% walnut shell added brake pad samples. They measured 85 Shore D and 87 Shore D hardness values from these samples, respectively (Akıncıoğlu et al., 2018). There are various factors that affect the hardness of brake pads such as production process, grain size of the materials (Maleque et al., 2012).

\subsection{Brake Pad Density Measurement}

The density value measured by the Arsimed principle was obtained as $2.340 \mathrm{gr} / \mathrm{cm}^{3}$ in the naturally additive samples, in the reference pad the value obtained $2.470 \mathrm{gr} / \mathrm{cm}^{3}$. This situation can be explained by the fact that the hazelnut shell is fibrous. Akıncıoğlu et al. In their study, observed that as the hazelnut shell powder increased, the density decreased (Akıncıoğlu et al., 2018).

\subsection{Wear-Friction Tests of Brake Pads}

Brake fade is the loss of brake effectiveness as a result of high temperature in the pad, usually under heavy braking conditions (Anderson, 1992). The change in speed and temperature at the interface of the disc and pad affect the friction coefficient. With increasing temperature and increasing sliding speed, the friction coefficient decreases (Anoop et al., 2009). High temperature during braking; It causes brake weakening, premature wear, evaporation of brake fluid, bearing failures, thermal cracks and vibrations. Temperature is one of the most important factors affecting braking performance (Zhang and Wang, 2007). Experiments on Chase type devices are carried out according to SAE J661 standards (Zhang and Wang, 2007). In the experiments, the friction coefficient value is determined five times and averaged. The average value found must be at least $0.25 \mu$. Three stages of friction test results of NUS sample; exercise, fayd and recovery processes are given in Table 1. The chart shows the variation of the friction coefficient according to temperature and applied forces.

Tablo 1. Friction test results of the hazelnut shell powder added sample.

\begin{tabular}{|c|c|c|c|c|c|c|c|c|}
\hline \multicolumn{3}{|c|}{ Baseline-1 } & \multicolumn{3}{|c|}{ Fade-1 } & \multicolumn{3}{|c|}{ Recovery-1 } \\
\hline $\begin{array}{l}\text { App. } \\
\text { No }\end{array}$ & $\begin{array}{c}\text { Friciton } \\
\text { Load } \\
(\mathrm{kg})\end{array}$ & $\begin{array}{c}\text { Friction } \\
\text { Coefficient } \\
(\mu)\end{array}$ & $\begin{array}{c}\text { Temperature } \\
{ }^{\circ} \mathrm{C}\end{array}$ & $\begin{array}{c}\text { Friciton } \\
\text { Load } \\
(\mathrm{kg})\end{array}$ & $\begin{array}{c}\text { Sürtünme } \\
\text { Katsay1sı } \\
(\mu)\end{array}$ & $\begin{array}{c}\text { Temperature } \\
{ }^{\circ} \mathrm{C}\end{array}$ & $\begin{array}{c}\text { Friciton } \\
\text { Load } \\
(\mathrm{kg})\end{array}$ & $\begin{array}{l}\text { Friction } \\
\text { Coefficient } \\
(\mu)\end{array}$ \\
\hline 1 & 16 & 0.244 & 93 & 15 & 0.237 & 261 & 22 & 0.339 \\
\hline 5 & 15 & 0.229 & 121 & 17 & 0.263 & 205 & 24 & 0.367 \\
\hline 10 & 14 & 0.215 & 149 & 18 & 0.279 & 149 & 25 & 0.366 \\
\hline 15 & 14 & 0.217 & 177 & 19 & 0.292 & 93 & 22 & 0.338 \\
\hline 20 & 15 & 0.229 & 205 & 20 & 0.307 & - & - & - \\
\hline- & - & - & 233 & 20 & 0.312 & - & - & - \\
\hline- & - & - & 261 & 21 & 0.323 & - & - & - \\
\hline- & - & - & 289 & 20 & 0.309 & - & - & - \\
\hline \multicolumn{2}{|c|}{ Average } & 0.227 & \multicolumn{2}{|c|}{ Average } & 0.29 & Average & & 0.353 \\
\hline \multicolumn{3}{|c|}{ Baseline -2 } & \multicolumn{3}{|c|}{ Fade-2 } & \multicolumn{3}{|c|}{ Recovery -2 } \\
\hline 1 & 23 & 0.356 & 93 & 25 & 0.38 & 317 & 28 & 0.419 \\
\hline 5 & 25 & 0.385 & 121 & 28 & 0.42 & 261 & 30 & 0.451 \\
\hline 10 & 24 & 0.367 & 149 & 29 & 0.44 & 205 & 30 & 0.464 \\
\hline 15 & 23 & 0.352 & 177 & 28 & 0.43 & 149 & 29 & 0.445 \\
\hline 20 & 23 & 0.356 & 205 & 28 & 0.43 & 93 & 23 & 0.358 \\
\hline- & - & - & 233 & 28 & 0.44 & - & - & - \\
\hline- & - & - & 261 & 29 & 0.44 & - & - & - \\
\hline- & - & - & 289 & 27 & 0.42 & - & - & - \\
\hline- & - & - & 317 & 25 & 0.37 & - & - & - \\
\hline- & - & - & 346 & 22 & 0.34 & - & - & - \\
\hline \multicolumn{2}{|c|}{ Average } & 0.435 & \multicolumn{2}{|c|}{ Average } & 0.451 & Average & & 0.427 \\
\hline \multicolumn{3}{|c|}{ Baseline -3} & \multicolumn{3}{|c|}{ Fade-3 } & \multicolumn{3}{|c|}{ Recovery -3 } \\
\hline 1 & 23 & 0.352 & 100 & 21 & 0.307 & 450 & 24 & 0.368 \\
\hline 5 & 24 & 0.372 & 200 & 29 & 0.449 & 350 & 27 & 0.415 \\
\hline 10 & 25 & 0.382 & 300 & 29 & 0.450 & 250 & 28 & 0.428 \\
\hline
\end{tabular}




\begin{tabular}{rrrrrcccc}
15 & 25 & 0.381 & 400 & 19 & 0.293 & 150 & 27 & 0.411 \\
20 & 24 & 0.366 & - & - & - & - & - & - \\
\multicolumn{2}{c}{ Average } & 0.371 & Average & & 0.167 & Average & 0.499
\end{tabular}

The friction coefficient progressed stable in the first stages of the baselien-1, fade and recovery processes of the NUS sample. The friction coefficient, which was $0.237 \mu$ when the temperature increased to $93{ }^{\circ} \mathrm{C}$, became $0.309 \mu$ when the temperature increased to $289{ }^{\circ} \mathrm{C}$. When the temperature increases, the friction coefficient is expected to decrease, but here it can be said that the increased friction force causes the friction coefficient to increase. In the recovery phase; The friction coefficient, which was $0.367 \mu$ at $205^{\circ} \mathrm{C}$, decreased to $0.338 \mu$ as the temperature decreased to $93{ }^{\circ} \mathrm{C}$. It can be thought that the decrease in temperature causes the friction coefficient to decrease (Österle and Urban, 2004). The friction coefficient of the NUS sample changed due to the increase in temperature in the second stages of the baseline-2, fade and recovery processes. In this process, the friction coefficients increased to a certain value and then its stability continued. In the third stage of the wear-friction tests, the highest temperature of $400{ }^{\circ} \mathrm{C}$ was reached. In the Feyd-3 phase, the friction coefficient decreased due to the high temperature, but increased again in the recovery phase and continued stable. It can be said that the friction coefficient of the NUS sample loses its stability after approximately 350 ${ }^{\circ} \mathrm{C}$. In this case, it is observed that hazelnut shell powder loses its effect at very high temperatures.

The friction coefficient test application graph of the NUS sample is given in Figure 3 for all three stages.
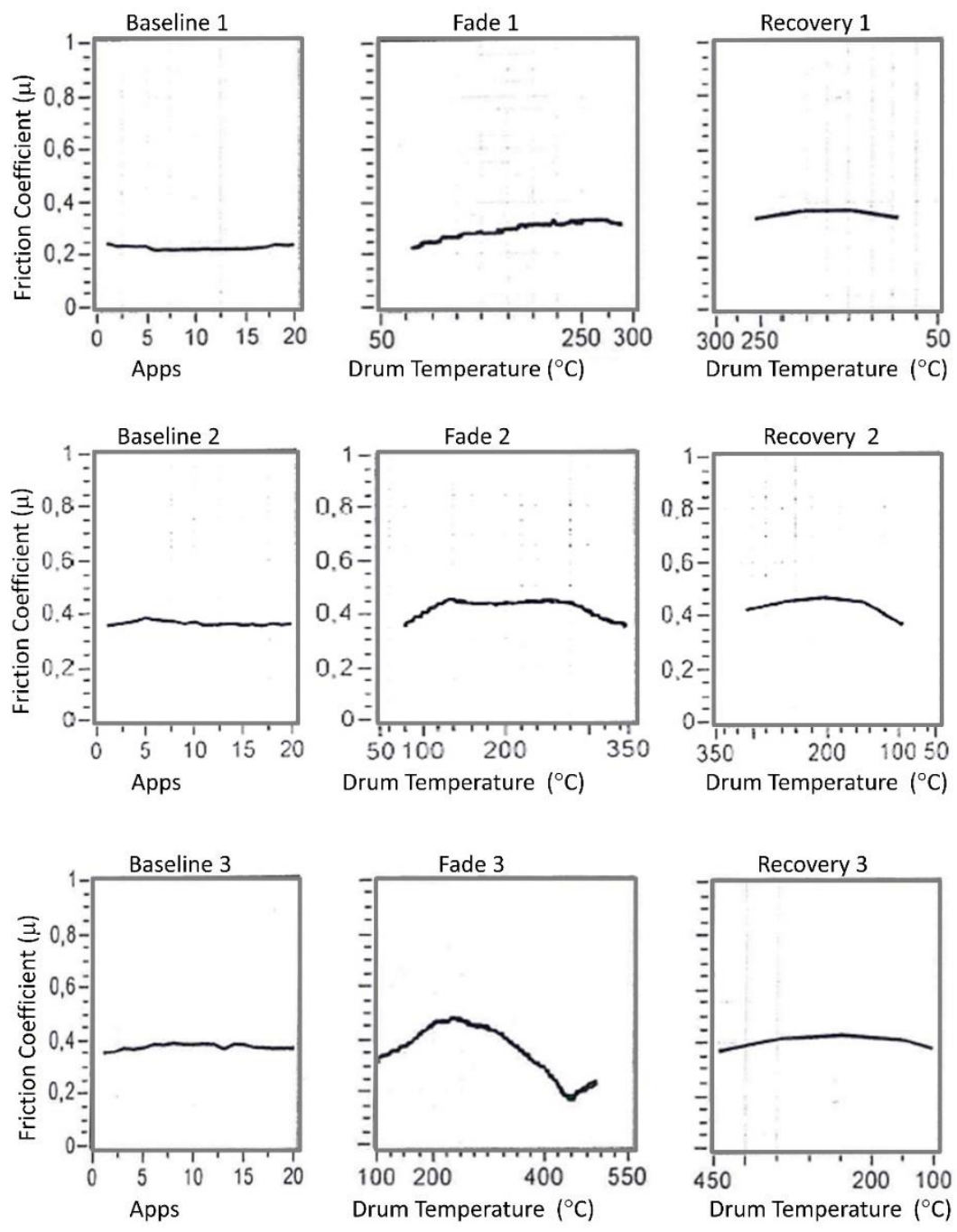

Figure 3. NUS numunesine ait sürtünme katsayısı test grafiği.

According to the friction coefficient plots of the NUS sample, there was a significant decrease in the friction coefficient only in the Fade-3 phase. The reason for this sudden decrease in the friction coefficient depends on

Experimental investigation on the friction characteristics of hazelnut powder reinforced brake pad, implies research results (Gülşah Akıncıoğlu) 
the high temperature. Since the temperature reached approximately $500{ }^{\circ} \mathrm{C}$, it caused a serious decrease in the friction coefficient. In other graphics, the friction coefficient is high and stable. It is observed that the friction coefficient of the NUS sample shows a good performance up to about $350{ }^{\circ} \mathrm{C}$, but after this temperature it loses its stability.

The average friction coefficient resulting from 100 braking of the NUS sample with hazelnut shell powder is shown in Table 2.

Table 2. The friction test results of the sample.

\begin{tabular}{ccc}
\hline Test No & Friction Force $(\mathrm{kg})$ & Friction Coefficient $(\mu)$ \\
\hline 1 & 26 & 0.403 \\
10 & 29 & 0.449 \\
20 & 28 & 0.453 \\
30 & 29 & 0.451 \\
40 & 29 & 0.449 \\
50 & 30 & 0.457 \\
60 & 29 & 0.453 \\
70 & 28 & 0.434 \\
80 & 28 & 0.433 \\
90 & 25 & 0.387 \\
100 & 27 & 0.412 \\
\hline
\end{tabular}

The average friction coefficient of the NUS sample with hazelnut shell powder after 100 applications is $0.435 \mu$ and this value is in compliance with the standards. It is observed that the friction coefficient is stable and does not increase or decrease suddenly. For a good braking performance, the friction coefficient is also expected to be constant. As a result of the tests, the letter symbols of the cold and hot friction coefficient of the NUS sample were obtained as "FF" according to the SAE J661 standard.

The interpretation of microstructure images has an important place in the analysis of brake pads. Many researchers have analyzed the microstructure of the brake pads they have produced (Fan et al., 2008). In Figure 4 , the microscope image of the NUS sample is given. It is seen in the microscope image that the powders forming the brake pad are homogeneously dispersed and formed a good structure.

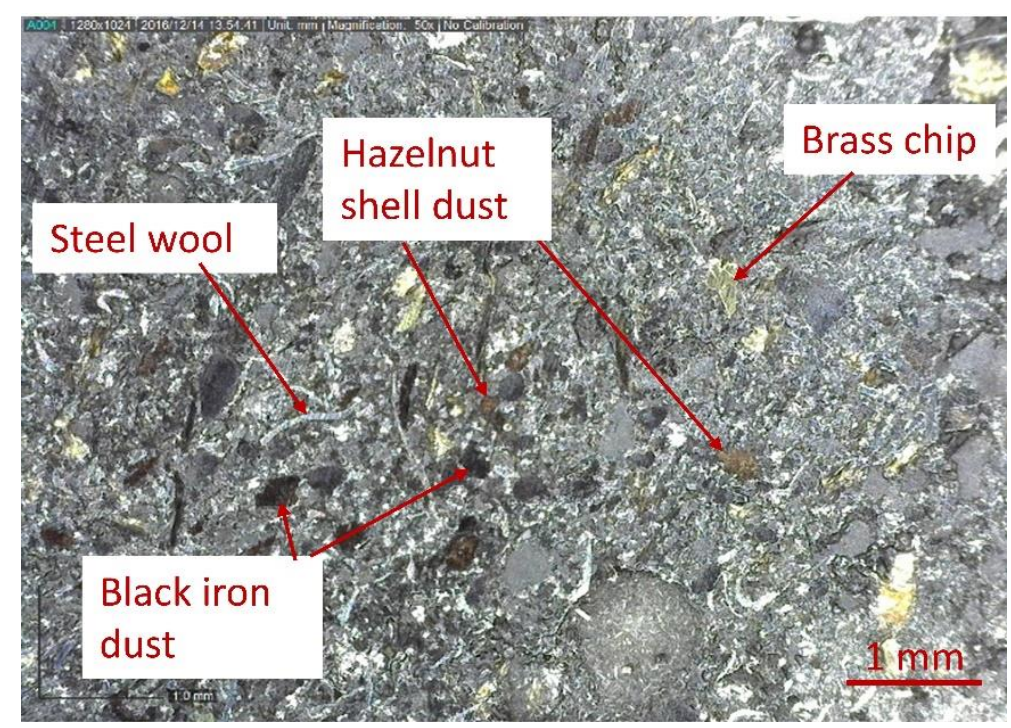

Figure 4. Microscope image of the NUS sample

The SEM image of NUS samples with hazelnut shell powder is shown in Figure 5. When the images are examined, it is observed that the hazelnut shell powders added to the composite are distributed homogeneously. Fan et al. In the SEM images they examined, the sample with the most $\mathrm{Al}_{2} \mathrm{O}_{3}$ in its content showed the most 
abrasion (Xin et al., 2007). Xin et al. (2007) in their studies, they observed the sisal particles and the friction layer in the lining samples they produced with sisal fiber on SEM images (Qi et al., 2014). Qi et al. (2014) observed the irregular friction layer in the SEM images of the pads they produced using hazelnut shell powder (Fu et al., 2012). Fu et al. (2012) In their studies, they were able to select the flax fibers, basalt fiber and friction layer in the SEM images of the linen made using flax fiber.

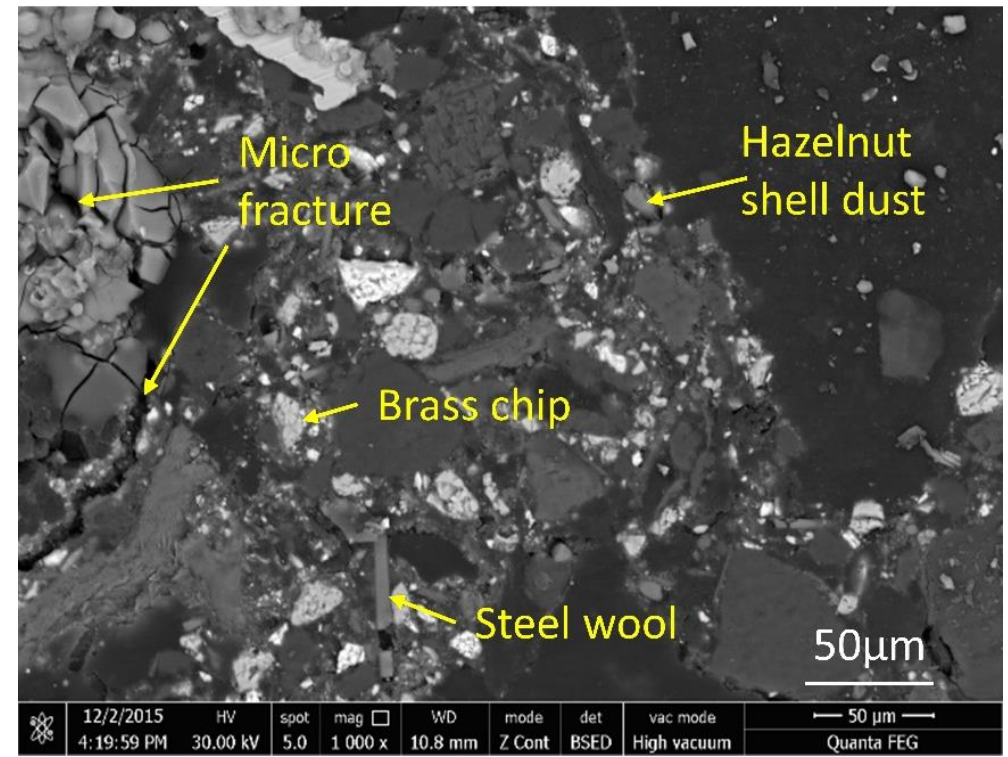

Figure 5. NUS numunesine ait SEM mikroyapı görüntüsü

SEM images of the NUS sample are given in Figure 5. Some microcracks are seen in the images.

\section{Conclusion}

The following results were obtained in our study to evaluate the hazelnut shell powder, which is a common production in our country, and to produce an environmentally friendly brake pad.

- A real-size brake pad was produced with the determined powders. There was no problem during the pressing process.

- Hardness and density values of the brake lining comply with the relevant standards.

- The friction coefficient value obtained as a result of the wear friction tests complies with SAE J661 standards. It can be said that the produced brake pad sample with natural additives can be used commercially.

\section{References}

Selikoff, I.J., Lee, D.H.K. (1978). Asbestos and diseaseCity: Academic Press, Inc.

Pinca-Bretotean, C., Josan, A., \& Birtok-Băneasă, C. (2018). Laboratory testing of brake pads made of organic materials intended for small and medium vehicles. IOP conference series: materials science and engineering, 393, 012029. https://doi.org/10.1088/1757-899X/393/1/012029.

Chan, D., \& Stachowiak, G. (2004). Review of automotive brake friction materials. Proceedings of the Institution of Mechanical Engineers, Part D: Journal of Automobile Engineering, 218, 953-66. https://doi.org/10.1243/0954407041856773.

Leman, Z., Sapuan, S., Saifol, A., Maleque, M.A., \& Ahmad, M. (2008). Moisture absorption behavior of sugar palm fiber reinforced epoxy composites. Materials \& Design, 29, 1666-70. https://doi.org/10.1016/j.matdes.2007.11.004. 
Singaravelu, D.L., Vijay, R., Manoharan, S., \& Kchaou, M. (2019). Development and performance evaluation of eco-friendly crab shell powder based brake pads for automotive applications. International Journal of Automotive and Mechanical Engineering, 16, 6502-6523. https://doi.org/10.15282/ijame.16.2.2019.4.0491.

Rajaraman, K.K., Joy, N., Balaji, T.S.C., Kumar, K.S., Mercy, J.L., Sivashankari, P. (2020). Evaluation of mechanical properties of brake pads prepared by organic fibres. AIP Conference Proceedings, 80-4. AIP Publishing LLC.

Öktem, H., \& Uygur, I. (2019). Advanced friction-wear behavior of organic brake pads using a newly developed system. Tribology Transactions, 62, 51-61. DOI: 10.1080/10402004.2018.1478054.

Jeganmohan, S., Sugozu, B., Kumar, M., \& Selvam, D.R. (2020). Experimental investigation on the friction and wear characteristics of palm seed powder reinforced brake pad friction composites. Journal of The Institution of Engineers (India): Series D, 101, 61-9. DOI: 10.1007/s40033-020-00210-9.

Sugozu, I. (2018). Investigation of friction performance related to use of pinus nigra cone powder in automotive brake pads. Int J Sci Technol Res, 4, 488-94.

Devoor, N., Sagar, P., \& Ramesh, D. (2018). Wear Behaviour of Brake Pad Material using Organic based Composite Materials. IJSTE - International Journal of Science Technology \& Engineering, 5, 36-40.

Akıncıoğlu, G., Öktem, H., Uygur, I., \& Akıncıŏlu, S. (2018). Determination of friction-wear performance and properties of eco-friendly brake pads reinforced with hazelnut shell and boron dusts. Arabian Journal for Science and Engineering, 43, 4727-37. https://doi.org/10.1007/s13369-018-3067-8.

Maleque, M., Atiqah, A., Talib, R., \& Zahurin, H. (2012). New natural fibre reinforced aluminium composite for automotive brake pad. International journal of mechanical and materials engineering, 7, 166-70.

Anderson, A.E. (1992). Friction and wear of automotive brakesCity.

Anoop, S., Natarajan, S., Kumaresh \& Babu, S.P. (2009). Analysis of factors influencing dry sliding wear behaviour of Al/SiCp-brake pad tribosystem. Materials \& Design, 30, 3831-8. https://doi.org/10.1016/j.matdes.2009.03.034.

Zhang, S., \& Wang, F. (2007). Comparison of friction and wear performances of brake material dry sliding against two aluminum matrix composites reinforced with different $\mathrm{SiC}$ particles. Journal of Materials Processing Technology, 182, 122-7. https://doi.org/10.1016/j.jmatprotec.2006.07.018.

Österle, W., \& Urban, I. (2004). Friction layers and friction films on PMC brake pads. Wear, 257, 215-26.

Fan, Y., Matějka, V., Kratošová, G., \& Lu, Y. (2008). Role of Al2O3 in semi-metallic friction materials and its effects on friction and wear performance. Tribology Transactions, 51, 771-8. 10.1080/10402000802011760.

Xin, X., Xu, C.G., \& Qing, L.F. (2007). Friction properties of sisal fibre reinforced resin brake composites. Wear, 262, 736-41. 10.1016/j.wear.2006.08.010.

Qi, S., Fu, Z., Yun, R., Jiang, S., Zheng, X., \& Lu, Y. (2014). Effects of walnut shells on friction and wear performance of eco-friendly brake friction composites. Proceedings of the Institution of Mechanical Engineers, Part J: Journal of Engineering Tribology, 228, 511-20. 10.1177/1350650113517112.

Fu, Z., Suo, B., Yun, R., Lu, Y., Wang, H., \& Qi, S. (2012). Development of eco-friendly brake friction composites containing flax fibers. Journal of Reinforced Plastics and Composites, 31, 681-9. $10.1177 / 0731684412442258$. 